\title{
12 Years Analysis of Bacterial Isolates and Their Antibiotics Sensitivity in a Tertiary Care Burns Unit
}

\author{
Said Saud Al-Busaidi1, Zainab Said Al-Hashimy², Adel Mohamed Hashish', \\ Sheikh Mohammad Ashik Iqbal Faruquee ${ }^{1}$, Hassan Ahmed Hamouda ${ }^{1}$, \\ Ahmed Osama Abdulhamed', Fawzi Mohamed Abdul-Aleem1 \\ ${ }^{1}$ Department of Plastic, Reconstructive and Craniofacial Surgery, Khoula Hospital, Muscat, \\ Sultanate of Oman \\ ${ }^{2}$ Directorate of Pharmacy and Medical Stores, Khoula Hospital, Muscat, Sultanate of Oman \\ Email: khallott@omantel.net.om
}

Received 7 May 2016; accepted 24 July 2016; published 27 July 2016

Copyright (C) 2016 by authors and Scientific Research Publishing Inc.

This work is licensed under the Creative Commons Attribution International License (CC BY). http://creativecommons.org/licenses/by/4.0/

c. (i) Open Access

\section{Abstract}

The aim of this study was to review the changes in distribution of bacterial populations and their antibiotic sensitivity over 12 years in a tertiary care burn unit. Understanding the periodic variation of isolated microorganisms and their antibiotic sensitivity helps in selecting the appropriate antimicrobial therapy before culture and sensitivity are reported. It also aids the design of antibiotics protocols. The study was retrospective. The data were obtained from the computerised hospital medical record system and the burn unit records. Overall, Pseudomonas aeruginosa was the most commonly isolated microorganism followed by Staphylococcus aureus, Meticillin-resistant Staphylococcus aureus (MRSA), and the genus Acinetobacter. Acinetobacter isolation rose rapidly and became more prevalent than $P$. aeruginosa over the last three years. Other organisms became isolated more frequently, such as Klebsiella pneumoniae, but their overall prevalence was low. Pseudomonas species frequency of isolation declined. P. aeruginosa, MRSA, and other microorganisms showed increasing sensitivity to a number of antibiotics. MRSA remained highly sensitive to vancomycin, and Acinetobacter showed high resistance to all antibiotics tested except colistin. $K$. pneumoniae was highly resistant to most of the antibiotics tested except the carbapenems, but the resistance to carbapenems increased over time.

\section{Keywords}

Burn, Microorganism, Antibiotic, Resistance, Sensitivity

How to cite this paper: Al-Busaidi, S.S., Al-Hashimy, Z.S., Hashish, A.M., Faruquee, S.M.A.I., Hamouda, H.A., Abdulhamed, A.O. and Abdul-Aleem, F.M. (2016) 12 Years Analysis of Bacterial Isolates and Their Antibiotics Sensitivity in a Tertiary Care Burns Unit. Modern Plastic Surgery, 6, 11-19. http://dx.doi.org/10.4236/mps.2016.63003 


\section{Introduction}

Infection is a frequent complication of burn injury. It is responsible for $75 \%$ of deaths in patients who sustain burns [1]. The increased risk of infection associated with burns is due to a number of factors. Two important factors are severe immunosuppression and loss of the skin barrier [1] [2]. When the skin barrier is lost, a burn wound is created. The burn wound is a good environment for microorganism growth because it is moist and contains necrotic tissues [3]-[5]. As a result, it becomes colonized rapidly by the skin flora, the bacteria that are usually present in the sweat glands and hair follicles.

The respiratory and gastrointestinal tracts can become additional sources of microorganisms. Invasive procedures, such as endotracheal intubation, invasive central venous or arterial lines, and urinary catheterization also increase the chances of infection [6]. Furthermore, organisms present in the hospital environment may be spread to the patient by health workers [3] [7] [8].

The pattern of bacterial isolates and antibiotic sensitivity is not constant, but changes with time. Understanding the periodic variation of isolated microorganisms and their antibiotic sensitivity helps in selecting the appropriate antimicrobial therapy before culture and sensitivity are reported [2] [9]. It also aids the design of antibiotics protocols.

The changing population patterns of microorganisms and their antibiotic sensitivities have become more complicated in recent years by the rise of antibiotic resistant microorganisms. The genus Acinetobacter has become a major problem in many burn units globally. Unfortunately, there are no new antibiotics to combat these resistant microorganisms. As a result, older, abandoned antibiotics have again become important in the management of antibiotic resistant microbes [10].

This report describes changes in the distribution of bacterial populations and their antibiotic sensitivity over 12 years at Khoula hospital burns unit. Khoula hospital is a tertiary care hospital and the burns unit is the only tertiary care burns unit in Sultanate of Oman.

\section{Methods}

The study was retrospective over 12 years and included all patients who were admitted to the Khoula Hospital burns unit from 01.01.2003 to 31.12.2014 and had positive cultures. The laboratory data were obtained from the computerised hospital medical record system [Al-Shifa Healthcare Information System] and the demographic data were obtained from burns unit records. Swab cultures, biopsy cultures, blood cultures, line cultures, secretion cultures and urine cultures were included. Patient demographic data and bacteriology reports of various cultures and their antibiotic sensitivities were reviewed. The data were entered into a spreadsheet and analysed using the Microsoft Office Excel 2007 program. We scored the presence of bacteria cultured from each patient during their visit. For example, if the patient had three consecutive positive swabs for a particular type of bacteria it was counted as one. The twelve-year period was divided into four three-year periods: 2003-2005, 20062008, 2009-2011 and 2012-2014. The number of admissions per year during the period of study was similar (mean/year: 191.25). The study was conducted with the approval of the hospital ethics committee.

\section{Results}

\subsection{Demographic Data (Table 1)}

A total of 2295 patients were admitted. There were 1402 (61\%) males and 893 (39\%) females. The number of adults was 1205 (53\%) and the number of children was 1090 (47\%). Scald was the most common cause of burns (1102 patients), followed by flame (860 patients), 316 (14\%) patients required ventilation, 138 (6\%) patients died.

\subsection{Bacterial Prevalence}

The total number of patients who had positive cultures was 1206 (53\%). The total number of isolates was 7110 . Fifty-seven isolates were excluded from the analysis as they were isolated sporadically and we considered them not significant. Therefore, 7053 isolates were included in the analysis of bacterial prevalence. Overall, Pseudomonas aeruginosa was the most common isolate (1607) followed by Staphylococcus aureus (1093), Meticillin resistant Staphylococcus aureus (MRSA) (1013), Acinetobacter (882), other Klebsiella species (537), Staphylococcus epidermidis (409), other Pseudomonas species (363), Escherichia coli (303), Enterococci (282), 
Table 1. Demographic data.

\begin{tabular}{|c|c|c|c|c|c|c|c|c|c|c|}
\hline & 2003-2005 & $\%$ & 2006-2008 & $\%$ & $2009-2011$ & $\%$ & 2012-2014 & $\%$ & Total & $\%$ \\
\hline Admission & 530 & & 541 & & 602 & & 622 & & 2295 & \\
\hline Inhalation & 66 & 12.5 & 69 & 12.8 & 82 & 13.6 & 99 & 15.9 & 316 & 13.8 \\
\hline Death & 31 & 5.8 & 22 & 4.1 & 40 & 6.6 & 45 & 7.2 & 138 & 6.0 \\
\hline Male & 335 & 63.2 & 319 & 59.0 & 362 & 60.1 & 386 & 62.1 & 1402 & 61.1 \\
\hline Female & 195 & 36.8 & 222 & 41.0 & 240 & 39.9 & 236 & 37.9 & 893 & 38.9 \\
\hline Adults & 251 & 47.4 & 282 & 52.1 & 329 & 54.7 & 343 & 55.1 & 1205 & 52.5 \\
\hline Children & 279 & 52.6 & 259 & 47.9 & 273 & 45.3 & 279 & 44.9 & 1090 & 47.5 \\
\hline \multicolumn{11}{|l|}{ TBSA Burned } \\
\hline$\leq 10 \%$ & 308 & 58.1 & 342 & 63.2 & 359 & 59.6 & 359 & 57.7 & 1368 & 59.6 \\
\hline $11 \%-20 \%$ & 117 & 22.1 & 105 & 19.4 & 105 & 17.4 & 137 & 22.0 & 464 & 20.2 \\
\hline $21 \%-50 \%$ & 77 & 14.5 & 65 & 12.0 & 108 & 17.9 & 93 & 15.0 & 343 & 14.9 \\
\hline$>51 \%$ & 28 & 5.3 & 29 & 5.4 & 30 & 5.0 & 33 & 5.3 & 120 & 5.2 \\
\hline \multicolumn{11}{|l|}{ Cause of Burn } \\
\hline Scald & 281 & 53.0 & 269 & 49.7 & 271 & 45.0 & 281 & 45.2 & 1102 & 48.0 \\
\hline Flame & 186 & 35.1 & 182 & 33.6 & 248 & 41.2 & 244 & 39.2 & 860 & 37.5 \\
\hline Electrical & 33 & 6.2 & 38 & 7.0 & 35 & 5.8 & 43 & 6.9 & 149 & 6.5 \\
\hline Chemical & 15 & 2.8 & 25 & 4.6 & 25 & 4.2 & 26 & 4.2 & 91 & 4.0 \\
\hline Friction & 1 & 0.2 & 4 & 0.7 & 5 & 0.8 & 5 & 0.8 & 15 & 0.7 \\
\hline Sun & 1 & 0.2 & 1 & 0.2 & 0 & 0.0 & 0 & 0.0 & 2 & 0.1 \\
\hline Contact & 11 & 2.1 & 22 & 4.1 & 17 & 2.8 & 23 & 3.7 & 73 & 3.2 \\
\hline Drug & 2 & 0.4 & 0 & 0.0 & 1 & 0.2 & 0 & 0.0 & 3 & 0.1 \\
\hline Total & 530 & & 541 & & 602 & & 622 & & 2295 & \\
\hline
\end{tabular}

Klebsiella pneumoniae (167) and Streptococcus (143). Other organisms that were less commonly isolated were Enterobacter (88), coliform bacteria (70), Proteus (69) and Serratia (27).

\subsection{Pattern of Isolates (Figure 1)}

\subsubsection{Gram-Positive}

Meticillin resistant Staphylococcus aureus (MRSA) was the most prevalent organism during the first period (2003-2005), where it was isolated 660 times. Subsequently, there was a sudden drop to 106 isolates in the second period and it remained static thereafter. During 2003-2005, MRSA was more prevalent than P. aeruginosa. S. aureus isolation was static throughout. The Staphylococcus epidermidis isolation rate rose progressively, from 71 times during 2003-2005 to 176 times during 2012-2014.

\subsubsection{Gram-Negative}

Acinetobacter was isolated infrequently during the period of 2003-2005 (31 isolates); however, after 2006 there was a dramatic rise, reaching 483 isolates by the period of 2012-2014. P. aeruginosa was the most commonly isolated Gram-negative organism until the period of 2012-2014, when Acinetobacter became the most prevalent, 


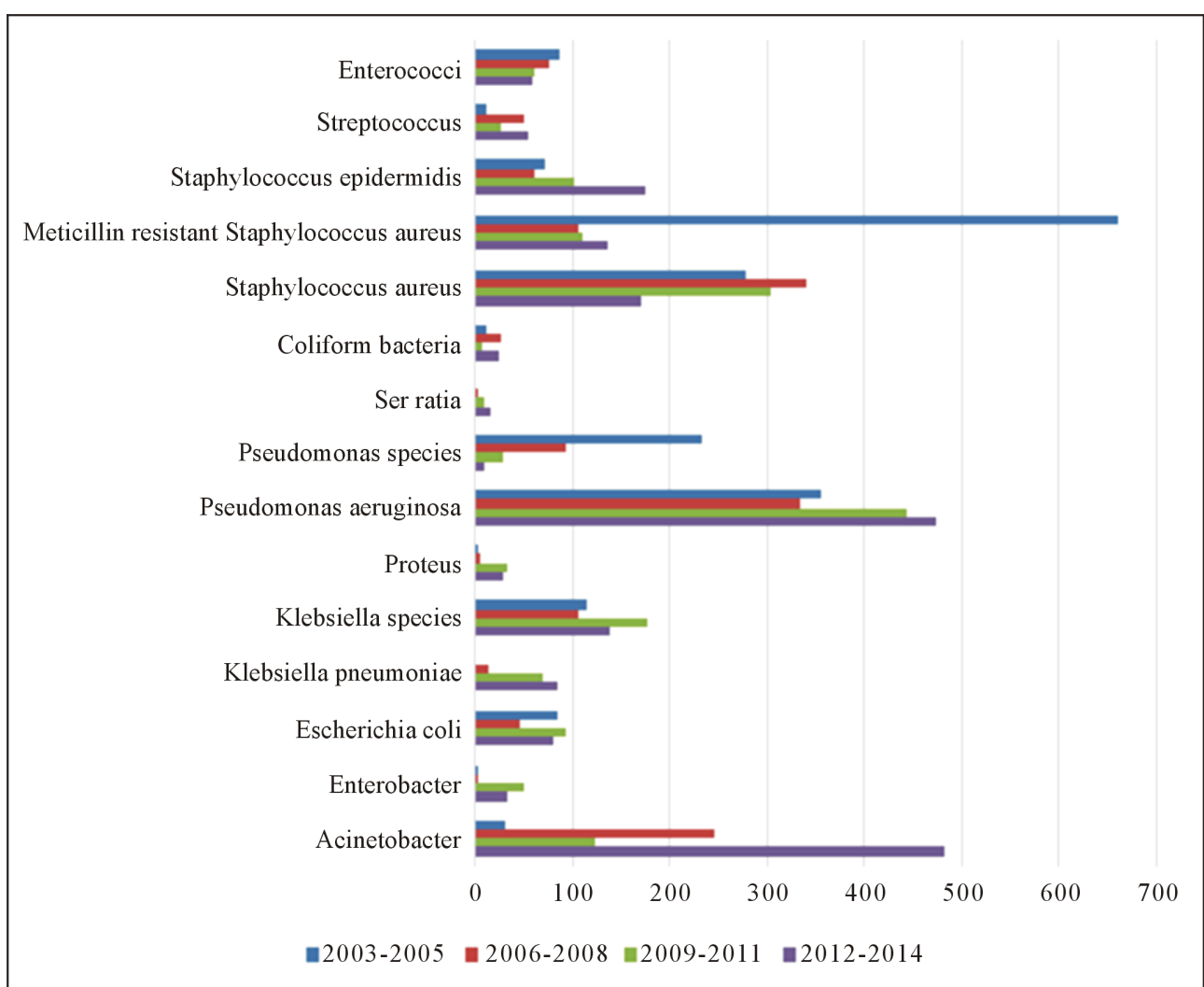

Figure 1. Pattern of bacterial isolates.

but the frequency of $P$. aeruginosa isolation continued to rise overall. The isolation of other Pseudomonas species reduced gradually over the four periods, dropping to 10 isolates only during the 2012-2014 period. K. pneumoniae was never isolated during the period of 2003-2005 and rose gradually to 84 isolates during the period of 2012-2014. Other Klebsiella species did not show any notable variation over the twelve-year period. Escherichia coli isolation was static over the study period.

\subsection{Pattern of Antibiotic Sensitivity}

\subsubsection{Gram-Positive (Table 2)}

S. aureus was always sensitive to all groups of antibiotics. Meticillin resistant Staphylococcus aureus (MRSA) was highly resistant to erythromycin, fucidate and gentamicin during the period of 2003-2005. Subsequently there was a gradual increase in sensitivity. Throughout the four periods, MRSA was highly sensitive to glycopeptides. Linezolid, rifampicin, and tigecycline were tested during the last period only and the sensitivity of MRSA to these antibiotics was $100.0 \%$.

S. epidermidis showed decreasing sensitivity to penicillins, lowering to about $10.0 \%$ sensitivity in 2012-2014. It was $100.0 \%$ sensitive to vancomycin during the 12 years while sensitivity to teicoplanin ranged from $95.0 \%$ to $100.0 \%$ during the period of study. Linezolid and rifampicin testing carried out in last three years of the study demonstrated $100.0 \%$ sensitivity of S. epidermis to these antibiotics.

Streptococcus was $100.0 \%$ sensitive to cephalosporins until the final study period, when the sensitivity dropped to about $50.0 \%$.

\subsubsection{Gram-Negative (Table 3)}

$P$. aeruginosa was highly sensitive to the piperacillin/tazobactam combination antibiotic throughout the study period. It was highly resistant to the cephalosporin group during the first two periods (2003-2005 and 20062008) whereas the sensitivity increased tremendously during the last two periods (2009-2011 and 2012-2014). With regard to the aminoglycoside and carbapenem groups, the period of 2006-2008 showed high resistance, but 
subsequently there was a high sensitivity. Quinolone sensitivity also increased during the last two periods. Colistin was tested during the last two periods and the sensitivity was $100.0 \%$.

Acinetobacter was $38.7 \%$ sensitive to the piperacillin/tazobactam combination antibiotic during the period of 2003-2005. This dropped to 6.1\% in 2012-2014. It did not show any significant sensitivity to cephalosporins or aminoglycosides. Sensitivity to ciprofloxacin dropped from $45.2 \%$ to $6.5 \%$. It was highly sensitive to imipenem (96.2\%) during the first period, but there was rise in resistance from 2006 onwards. With regard to colistin, the sensitivity was $100.0 \%$ during the period 2009-2011, and 99.2\% during 2012-2014.

Klebsiella species demonstrated high sensitivity to piperacillin/tazobactam throughout the study period whereas it showed low sensitivity to amoxicillin-clavulanate and ampicillin. Klebsiella sensitivity to cephalosporins rose over the 12-year period. A striking finding was that sensitivity to ceftazidime was $3.4 \%$ during 2003-2006 and 97.0\% during 2012-2014. Klebsiella species were also becoming more sensitive to aminoglycosides. The sensitivity to carbapenems and glycopeptides was stable and almost $100.0 \%$ throughout the 12 -year period.

E. coli was highly sensitive to carbapenems at all times tested and in the period of 2012-2014, the sensitivity was $100.0 \%$. Also, E. coli was highly sensitive to piperacillin/tazobactam and the aminoglycoside group at all times tested. Overall, E. coli sensitivity to cephalosporins reduced over time.

Table 2. Antibiotics sensitivity of Gram + ve bacteria.

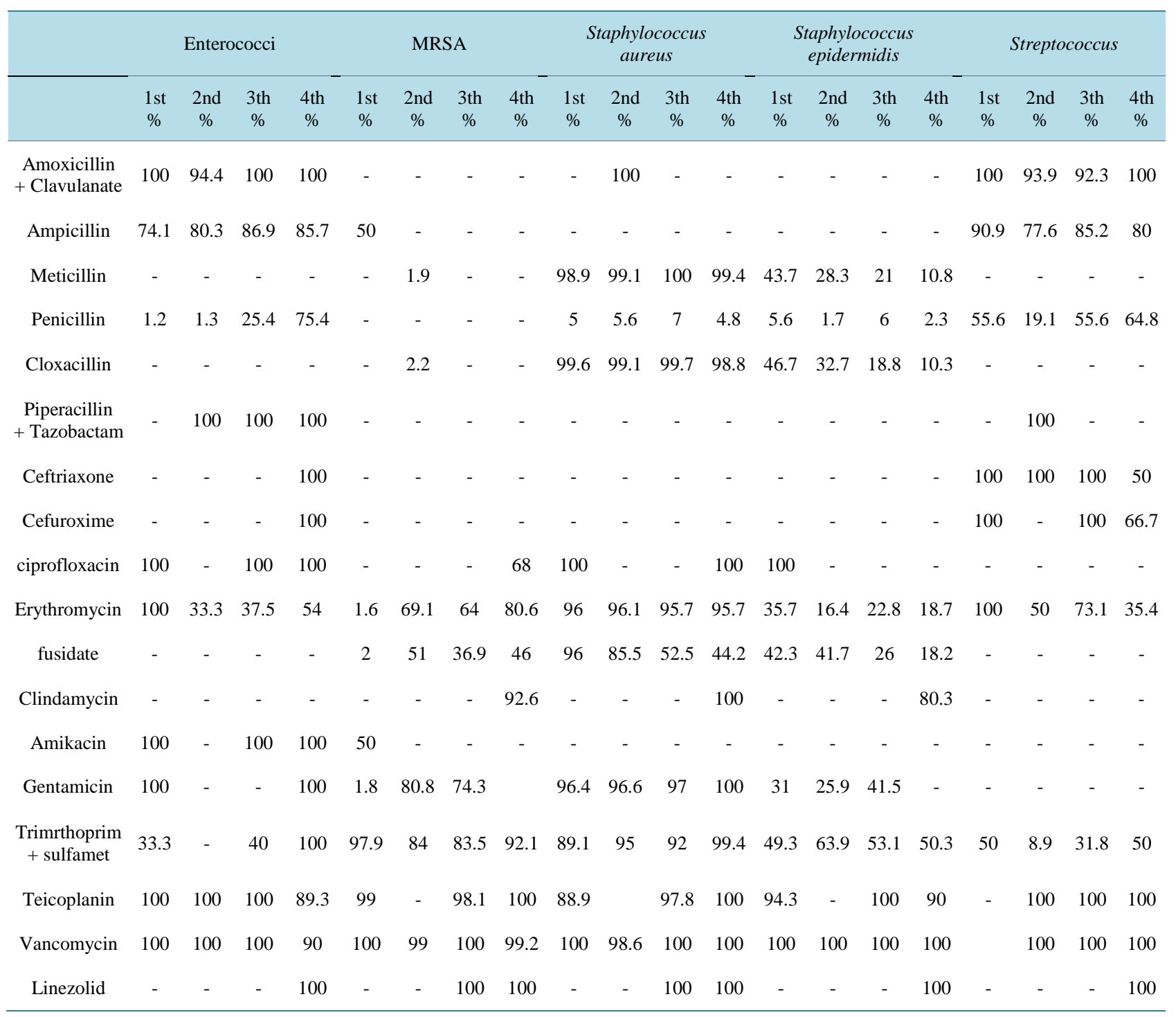


Table 3. Antibiotics sensitivity of Gram -ve bacteria.

\begin{tabular}{|c|c|c|c|c|c|c|c|c|c|c|c|c|c|c|c|c|c|c|c|c|}
\hline & \multicolumn{4}{|c|}{ Acinetobacter } & \multicolumn{4}{|c|}{ Coliform bacteria } & \multicolumn{4}{|c|}{ Enterobacter } & \multicolumn{4}{|c|}{ Escherichia coli } & \multicolumn{4}{|c|}{ Klebsiella pneumoniae } \\
\hline & $\begin{array}{l}1 \mathrm{st} \\
\%\end{array}$ & $\begin{array}{l}\text { 2nd } \\
\%\end{array}$ & $\begin{array}{l}\text { 3th } \\
\%\end{array}$ & $\begin{array}{l}4 \text { th } \\
\%\end{array}$ & $\begin{array}{l}1 \mathrm{st} \\
\%\end{array}$ & $\begin{array}{c}\text { 2nd } \\
\%\end{array}$ & $\begin{array}{l}\text { 3th } \\
\%\end{array}$ & $\begin{array}{c}4 \text { th } \\
\%\end{array}$ & $\begin{array}{l}1 \mathrm{st} \\
\%\end{array}$ & $\begin{array}{l}\text { 2nd } \\
\%\end{array}$ & $\begin{array}{c}\text { 3th } \\
\%\end{array}$ & $\begin{array}{l}4 \text { th } \\
\%\end{array}$ & $\begin{array}{l}1 \mathrm{st} \\
\%\end{array}$ & $\begin{array}{c}\text { 2nd } \\
\%\end{array}$ & $\begin{array}{l}\text { 3th } \\
\%\end{array}$ & $\begin{array}{l}\text { 4th } \\
\%\end{array}$ & $\begin{array}{l}1 \mathrm{st} \\
\%\end{array}$ & $\begin{array}{l}\text { 2nd } \\
\%\end{array}$ & $\begin{array}{l}\text { 3th } \\
\%\end{array}$ & $\begin{array}{c}\text { 4th } \\
\%\end{array}$ \\
\hline $\begin{array}{l}\text { Amoxicillin } \\
+ \text { Clavulanate }\end{array}$ & - & - & - & - & 36.4 & 24 & 14.3 & 20 & 100 & - & 2 & 6.1 & 48.8 & 53.3 & 43.3 & 49.4 & - & - & 17.4 & 17.1 \\
\hline Ampicillin & - & - & - & - & - & 3.8 & - & 4.2 & 50 & - & - & 3 & 7.4 & 20 & 5.2 & 17.5 & - & - & - & - \\
\hline $\begin{array}{l}\text { Piperacillin } \\
+ \text { Tazobactam }\end{array}$ & 38.7 & 4.5 & 26.9 & 6.1 & 100 & 85.7 & 83.3 & 79.2 & 100 & 100 & 89.4 & 96.8 & 73.1 & 86.8 & 92.7 & 97.3 & - & 64.3 & 87.9 & 69.6 \\
\hline Cefepime & 12.9 & 0.8 & 26.9 & 5.6 & 100 & 73.3 & 57.1 & 95.5 & 50 & 100 & 97.6 & 90.9 & 87.2 & 53.3 & 66.3 & 65 & - & 10 & 14.8 & 12.1 \\
\hline Cefotaxime & - & - & - & - & - & 40 & 57.1 & 80 & - & 100 & 60 & 84.8 & 100 & 31.6 & 55.9 & 62.5 & - & - & 7.5 & 11 \\
\hline Ceftriaxone & - & - & - & - & 83.3 & 40 & 57.1 & 80 & 100 & 100 & 60 & 87.9 & 81.6 & 35.3 & 54.2 & 61.3 & - & - & 7.2 & 11 \\
\hline Cefuroxime & - & - & - & - & 75 & 40.9 & 28.6 & 68 & 100 & 100 & 42 & 75.8 & 87.7 & 41.9 & 55.7 & 57.5 & - & - & 7.2 & 11 \\
\hline Cephradine & - & - & - & - & 18.2 & 30.4 & 14.3 & 26.7 & 25 & - & - & - & 81.5 & 42.9 & 40.2 & 39.1 & - & - & 5.8 & 15.4 \\
\hline Ciprofloxacin & 45.2 & 2.9 & 32.8 & 6.5 & 100 & 66.7 & 71.4 & 84 & 100 & 100 & 85.7 & 87.9 & 61.3 & 65 & 70.1 & 63.8 & - & 14.3 & 60.9 & 48.8 \\
\hline Amikacin & 22.6 & 0.8 & 28.7 & 8.6 & 100 & 89.5 & 100 & 95.8 & 100 & 100 & 90 & 96.9 & 84.5 & 90.5 & 97.9 & 97.3 & - & 78.6 & 92.8 & 69.3 \\
\hline Gentamicin & - & 1.3 & 23.8 & 7.3 & 83.3 & 47.8 & 57.1 & 84 & 100 & 100 & 64 & 90.9 & 74.4 & 74.3 & 45.2 & 72.2 & - & - & 30.4 & 34.6 \\
\hline Imipenem & 96.2 & 10.5 & 28.7 & 6.3 & 100 & 90.9 & 100 & 96 & - & 100 & 100 & 100 & 90 & 100 & 100 & 100 & - & 100 & 100 & 74.7 \\
\hline Meropenem & 37.5 & 4.6 & 25.4 & 6.7 & 100 & 90 & 100 & 100 & - & 100 & 100 & 100 & 91.3 & 78.6 & 100 & 100 & - & 100 & 100 & 76.7 \\
\hline \multirow[t]{3}{*}{ Colistin } & - & - & 100 & 99.2 & - & - & - & - & - & - & - & 100 & 29.6 & 50 & 30.5 & 35.9 & - & - & - & - \\
\hline & \multicolumn{4}{|c|}{ Klebsiella species } & \multicolumn{4}{|c|}{ Proteus } & \multicolumn{4}{|c|}{$\begin{array}{c}\text { Pseudomonas } \\
\text { aeruginosa }\end{array}$} & \multicolumn{4}{|c|}{$\begin{array}{l}\text { Pseudomonas } \\
\text { species }\end{array}$} & \multicolumn{4}{|c|}{ Serratia } \\
\hline & $\begin{array}{l}1 \mathrm{st} \\
\%\end{array}$ & $\begin{array}{c}\text { 2nd } \\
\%\end{array}$ & $\begin{array}{l}\text { 3th } \\
\%\end{array}$ & $\begin{array}{l}4 \text { th } \\
\%\end{array}$ & $\begin{array}{l}1 \mathrm{st} \\
\%\end{array}$ & $\begin{array}{c}\text { 2nd } \\
\%\end{array}$ & $\begin{array}{l}\text { 3th } \\
\%\end{array}$ & $\begin{array}{l}4 \text { th } \\
\%\end{array}$ & $\begin{array}{l}1 \mathrm{st} \\
\%\end{array}$ & $\begin{array}{c}\text { 2nd } \\
\%\end{array}$ & $\begin{array}{l}\text { 3th } \\
\%\end{array}$ & $\begin{array}{l}4 \text { th } \\
\%\end{array}$ & $\begin{array}{l}1 \mathrm{st} \\
\%\end{array}$ & $\begin{array}{c}\text { 2nd } \\
\%\end{array}$ & $\begin{array}{l}\text { 3th } \\
\%\end{array}$ & $\begin{array}{c}4 \text { th } \\
\%\end{array}$ & $\begin{array}{l}1 \mathrm{st} \\
\%\end{array}$ & $\begin{array}{c}\text { 2nd } \\
\%\end{array}$ & $\begin{array}{l}\text { 3th } \\
\%\end{array}$ & $\begin{array}{c}\text { 4th } \\
\%\end{array}$ \\
\hline $\begin{array}{l}\text { Amoxicillin } \\
+ \text { Clavulanate }\end{array}$ & 48.7 & 26.7 & 35.8 & 63.5 & 100 & 100 & 85.7 & 85.7 & - & - & - & - & - & - & - & - & - & - & - & - \\
\hline Ampicillin & 3.5 & 1 & 0.6 & 1.5 & 100 & 25 & 22.9 & 17.9 & - & - & - & - & - & - & - & - & - & - & - & - \\
\hline $\begin{array}{l}\text { Piperacillin } \\
+ \text { Tazobactam }\end{array}$ & 82.8 & 71.9 & 88.3 & 93.2 & - & 100 & 100 & 93.1 & 85.4 & 83.8 & 93.9 & 81.8 & 82 & 87.1 & 81.5 & 75 & - & 100 & 88.9 & 87.5 \\
\hline Cefepime & 65.6 & 63.3 & 89.4 & 98.3 & & - & 100 & 94.4 & 49.3 & 42.7 & 94 & 84.4 & 42.3 & 33.3 & 73.9 & 77.8 & - & 100 & 88.9 & 92.9 \\
\hline Cefotaxime & 33.3 & 24.6 & 74.4 & 94.2 & - & - & 100 & 96.4 & - & - & - & - & - & - & - & - & - & - & 77.8 & 93.8 \\
\hline Ceftazidime & 3.4 & 25 & 75.7 & 97 & - & - & 100 & 96.3 & 26.6 & 25.4 & 90.8 & 81.4 & 23 & 20.6 & 82.1 & 88.9 & - & 50 & 88.9 & 93.8 \\
\hline Ceftriaxone & 39.1 & 23 & 74 & 94.2 & - & - & 100 & 96.4 & - & - & - & - & - & - & - & - & - & - & 77.8 & 93.8 \\
\hline Cefuroxime & 75 & 31.2 & 69.3 & 89.1 & 100 & - & 91.4 & 88.9 & - & - & - & - & 100 & - & - & - & - & - & - & - \\
\hline Cephradine & 51.3 & 25.8 & 36.7 & 69.3 & - & 20 & 20 & 41.2 & - & - & - & - & - & - & - & - & - & - & - & 18.2 \\
\hline Ciprofloxacin & 79.6 & 76.3 & 84.1 & 96.3 & - & 40 & 100 & 88.5 & 67.9 & 63.9 & 93 & 91.4 & 54.3 & 42.2 & 82.1 & 88.9 & - & 100 & 88.9 & 100 \\
\hline
\end{tabular}




\begin{tabular}{|c|c|c|c|c|c|c|c|c|c|c|c|c|c|c|c|c|c|c|c|c|}
\hline \multicolumn{21}{|l|}{ Continued } \\
\hline Amikacin & 93.8 & 78.2 & 94.3 & 99.2 & - & 100 & 100 & 100 & 70.8 & 47.7 & 86.1 & 90.5 & 65.2 & 43.2 & 71.4 & 88.9 & - & 50 & 100 & 100 \\
\hline Gentamicin & 68.8 & 51.6 & 68.8 & 94.8 & 100 & 33.3 & 97.1 & 85.7 & 59 & 41.8 & 75.5 & 87.5 & 43.5 & 34.1 & 50 & 77.8 & - & 100 & 77.8 & 100 \\
\hline Imipenem & 100 & 95.2 & 99.4 & 100 & - & - & 100 & 100 & 55.2 & 34.8 & 86.3 & 76.2 & 64 & 40 & 80.8 & 70 & - & 100 & 100 & 100 \\
\hline Meropenem & 100 & 95.6 & 100 & 100 & - & - & 100 & 100 & 52.8 & 31.9 & 92.5 & 80.3 & 47.9 & 32.1 & 82.1 & 77.8 & - & 100 & 100 & 100 \\
\hline $\begin{array}{c}\text { Trimethoprim } \\
+ \text { Sulfamethoxazole }\end{array}$ & 47.6 & 33 & 64 & 78.8 & 100 & 40 & 74.2 & 72 & - & - & 20 & - & - & - & - & - & - & 100 & 77.8 & 100 \\
\hline Colistin & - & - & - & - & - & - & - & - & - & - & 100 & 100 & - & - & - & - & - & - & - & - \\
\hline
\end{tabular}

Pseudomonas species demonstrated intermediate sensitivity to all tested antibiotics, Enterococci did not show any significant resistance and Klebsiella pneumoniae was highly resistant to most of the antibiotics except the carbapenems. During the period of 2012-2014, the sensitivity to carbapenems declined. K. pneumoniae demonstrated intermediate sensitivity to piperacillin/tazobactam and amikacin.

\section{Discussion}

P. aeruginosa, S. aureus and MRSA are the most commonly isolated microorganisms worldwide [9] [11]-[18]. This pattern of distribution appears to be constant and does not change over time. In a review of 50 years of isolates, S. aureus and P. aeruginosa were the most commonly isolated organisms [5]. This is a global phenomenon and the pattern in our burns unit was not different.

On the other hand, there has been a sharp rise in Acinetobacter isolation over recent years. Acinetobacter was rarely isolated before 1970 [5]. In older reports, Acinetobacter either did not grow at all [19], or was isolated but its presence was not that significant. Acinetobacter is now recognized as a microorganism that is isolated early in hospitalization [20] [21]. Furthermore, a recent report named Acinetobacter baumannii as the most prevalent organism in a tropical burn unit [22]. We also found that Acinetobacter became the most prevalent isolate in the last three years of the study and the fourth most common isolate overall. Acinetobacter has become resistant to most common antibiotics, also referred to as multi-drug resistant (MDR). This has a negative impact on burn patients as treating infection and septicaemia is very difficult in the presence of MDR Acinetobacter. Empirical antibiotic therapy should consider the growing prevalence of such MDR organisms.

There is a global rise in antibiotic resistance [23]-[26]. In our burns unit, we found that Acinetobacter was resistant to almost all of the antibiotics available except colistin. According to some reports, Acinetobacter demonstrated high sensitivity to carbapenems [9] [27]. Such was the case in our unit until 2005, after which the resistance of Acinetobacter to carbapenems increased to more than $90 \%$.

Another organism isolated increasingly is K. pneumoniae. Unfortunately, it shows increasing resistance to most antibiotics now, including the carbapenems. In the US, $K$. pneumoniae resistance to carbapenems began in late 1990s [28]; in our unit, the resistance appeared in 2012.

Bacterial sensitivity to antibiotics varies according to the organism, the antibiotic used and time. MRSA was reported by some centres to be resistant to vancomycin [25] [29]. Fortunately, MRSA susceptibility to vancomycin remained at nearly $100 \%$ in our unit. In fact, MRSA demonstrated increasing susceptibility to many antibiotics over the study period.

We also found increasing susceptibility to antibiotics in other organisms like Klebsiella species, and $P$. aeruginosa. Similar findings regarding Pseudomonas aeruginosa sensitivity were reported previously by other centres [26]. On the other hand, other investigators found increasing resistance of $P$. aeruginosa to antibiotics [13]. In our unit, MDR Pseudomonas aeruginosa is still a rare occurrence.

The infection control measures taken by our hospital, and the burns unit in particular, to control MDR Acinetobacter and MRSA are: strict hand hygiene; screening of the patients at the referring hospital and after arrival to the burns unit; strict isolation of colonized and infected cases; protective aprons, masks and gloves when staff are in contact with the patients; restricting the visitors to two per day; and regular auditing and rounds by the infection control nurse.

Despite infection control measures, the control of MDR Acinetobacter is difficult. Burns patients require pro- 
longed hospital stays and some require prolonged ventilation as well as indwelling lines and catheters. The immunity of these patients is depressed and their wound recovery is slow. All of these factors increase the risk of infection. As might be expected, the majority of mortalities in our unit have MDR Acinetobacter growth.

The rise in MDR organisms is a global phenomenon. There is a need for new antibiotics to control such organisms. We observed in this review that microorganisms were sensitive to antibiotics that have been out of use for a long time.

\section{Conclusion}

In our hospital burns units, $P$. aeruginosa remains the most commonly isolated organism overall, followed by $S$. aureus and MRSA. Multidrug resistant Acinetobacter prevalence is increasing and colistin remains the only antibiotic that is effective against it. Enterobacteria, carbapenem-resistant, were isolated occasionally suggesting their growing prevalence. Although certain organisms demonstrate increasing resistance to antibiotics, other organisms display increasing sensitivity. MRSA is highly sensitive to vancomycin and shows a progressive rise in sensitivity to a number of antibiotics.

\section{Conflict of Interest}

All authors declare that they have no conflict of interest.

\section{Acknowledgements}

The authors would like to thank Ishaq Ali Al-Aghbari (hospital statistician) and Shakeel Ahammed (IT Department) for helping in data analysis and retrieval.

\section{References}

[1] Garcia Bernal, F.J., Torrero, V., Regalado, J. and Gabilondo, F.J. (2000) Bacteriology in Burn Patients Undergoing Mechanical Ventilation. Burns, 26, 731-736. http://dx.doi.org/10.1016/S0305-4179(00)00055-3

[2] Revathi, G., Puri, J. and Jain, B.K. (1998) Bacteriology of Burns. Burns, 24, 347-349. http://dx.doi.org/10.1016/S0305-4179(98)00009-6

[3] Fadeyibi, I.O., Raji, M.A., Ibrahim, N.A., Ugburo, A.O. and Ademiluyi, S. (2013) Bacteriology of Infected Burn Wounds in the Burn Wards of a Teaching Hospital in Southwest Nigeria. Burns, 39, 168-173. http://dx.doi.org/10.1016/j.burns.2012.02.005

[4] Ozumba, U.C. and Jiburum, B.C. (2000) Bacteriology of Burn Wounds in Enugu, Nigeria. Burns, 26, 178-180. http://dx.doi.org/10.1016/S0305-4179(99)00075-3

[5] Lawrence, J.C. (1992) Burn Bacteriology during the Last 50 Years. Burns, 18, S23-S29. http://dx.doi.org/10.1016/0305-4179(92)90066-4

[6] Guggenheim, M., Thurnheer, T., Gmür, R., Giovanoli, P. and Guggenheim, B. (2011) Validation of the Zürich BurnBiofilm Model. Burns, 37, 1125-1133. http://dx.doi.org/10.1016/j.burns.2011.05.017

[7] Erol, S., Altoparlak, U., Akcay, M.N., Celebi, F. and Parlak, M. (2004) Changes of Microbial Flora and Wound Colonization in Burned Patients. Burns, 30, 357-361. http://dx.doi.org/10.1016/j.burns.2003.12.013

[8] Magnotti, L.J. and Deitch, E.A. (2005) Burns, Bacterial Translocation, Gut Barrier Function, and Failure. Journal of Burn Care \& Rehabilitation, 26, 383-391. http://dx.doi.org/10.1097/01.bcr.0000176878.79267.e8

[9] Guggenheim, M., Zbinden, R., Handschin, A.E., Gohritz, A., Altintas, M.A. and Giovanoli, P. (2009) Changes in Bacterial Isolates from Burn Wounds and Their Antibiograms: A 20-Year Study (1986-2005). Burns, 35, 553-560. http://dx.doi.org/10.1016/j.burns.2008.09.004

[10] Al-Busaidi, S., Mohammed, A., Murugan, V.K. and Thankappan, S. (2013) Colistin Effectiveness and Nephrotoxicity: Experience from a Tertiary Care Burns Unit in Oman. European Journal of Plastic Surgery, 36, 443-448. http://dx.doi.org/10.1007/s00238-013-0827-2

[11] Agnihotri, N., Gupta, V. and Joshi, R.M. (2004) Aerobic Bacterial Isolates from Burn Wound Infections and Their Antibiograms-A Five-Year Study. Burns, 30, 241-243. http://dx.doi.org/10.1016/j.burns.2003.11.010

[12] Mousa, H.A. (1997) Aerobic, Anaerobic and Fungal Burn Wound Infection. Journal of Hospital Infection, 37, $317-323$. http://dx.doi.org/10.1016/S0195-6701(97)90148-1

[13] Elmanama, A.A., Al Laham, N.A. and Tayh, G.A. (2013) Antimicrobial Susceptibility of Bacterial Isolates from Burn 
Units in Gaza. Burns, 39, 1612-1618. http://dx.doi.org/10.1016/j.burns.2013.04.011

[14] Singh, N.P., Goyal, R., Manchanda, V., Das, S., Kaur, I. and Talwar, V. (2003) Changing Trends in Bacteriology of Burns in the Burns Unit, Delhi, India. Burns, 29, 129-132. http://dx.doi.org/10.1016/S0305-4179(02)00249-8

[15] Donati, L., Scamazzo, F., Gervasoni, M., Magliano, A., Stankov, B. and Fraschini, F. (1993) Infection and Antibiotic Therapy in 4000 Burned Patients Treated in Milan, Italy, between 1976 and 1988. Burns, 19, 345-348. http://dx.doi.org/10.1016/0305-4179(93)90125-R

[16] Hodle, A.E., Richter, K.P. and Thompson, R.M. (2006) Infection Control Practices in US Burn Units. Journal of Burn Care \& Research, 27, 142-151. http://dx.doi.org/10.1097/01.BCR.0000203493.31642.79

[17] Khorasani, G., Salehifar, E. and Eslami, G. (2008) Profile of Microorganisms and Antimicrobial Resistance at a Tertiary Care Referral Burn Centre in Iran: Emergence of Citrobacter freundii as a Common Microorganism. Burns, 34, 947-952. http://dx.doi.org/10.1016/j.burns.2007.12.008

[18] Komolafe, O.O., James, J., Kalongolera, L. and Makoka, M. (2003) Bacteriology of Burns at the Queen Elizabeth Central Hospital, Blantyre, Malawi. Burns, 29, 235-238. http://dx.doi.org/10.1016/S0305-4179(02)00273-5

[19] Yemul, V.L. and Sengupta, S.R. (1981) Bacteriology of Burns. Burns, 7, 190-193. http://dx.doi.org/10.1016/0305-4179(81)90063-2

[20] Keen, E.F., Robinson, B.J., Hospenthal, D.R., Aldous, W.K., Wolf, S.E., Chung, K.K. and Murray, C.K. (2010) Incidence and Bacteriology of Burn Infections at a Military Burn Center. Burns, 36, 461-468. http://dx.doi.org/10.1016/j.burns.2009.10.012

[21] Wolf, S.E., Sterling, J.P., Hunt, J.L. and Arnoldo, B.D. (2011) The Year in Burns 2010. Burns, 37, $1275-1287$. http://dx.doi.org/10.1016/j.burns.2011.10.001

[22] Chong, S.J., Ahmed, S., Tay, J.M., Song, C. and Tan, T.T. (2011) 5 Year Analysis of Bacteriology Culture in a Tropical Burns ICU. Burns, 37, 1349-1353. http://dx.doi.org/10.1016/j.burns.2011.07.020

[23] Keen, E.F., Robinson, B.J., Hospenthal, D.R., Aldous, W.K., Wolf, S.E., Chung, K.K. and Murray, C.K. (2010) Prevalence of Multidrug-Resistant Organisms Recovered at a Military Burn Center. Burns, 36, 819-825. http://dx.doi.org/10.1016/j.burns.2009.10.013

[24] Lautenbach, E. and Polk, R.E. (2007) Resistant Gram-Negative Bacilli: A Neglected Healthcare Crisis? American Journal of Health-System Pharmacy, 64, S3-S21. http://dx.doi.org/10.2146/ajhp070477

[25] Edwards-Jones, V. and Greenwood, J.E. (2003) Manchester Burns Research Group. What's New in Burn Microbiology? James Laing Memorial Prize Essay 2000. Burns, 29, 15-24. http://dx.doi.org/10.1016/S0305-4179(02)00203-6

[26] Sun, F.J., Zhang, X.B., Fang, Y., Chen, J., Xing, H., Shi, H., Feng, W. and Xia, P. (2012) Spectrum and Drug Resistance of Pathogens from Patients with Burns. Burns, 38, 1124-1130. http://dx.doi.org/10.1016/j.burns.2012.05.018

[27] Rezaei, E., Safari, H., Naderinasab, M. and Aliakbarian, H. (2011) Common Pathogens in Burn Wound and Changes in Their Drug Sensitivity. Burns, 37, 805-807. http://dx.doi.org/10.1016/j.burns.2011.01.019

[28] Sanchez, G.V., Master, R.N., Clark, R.B., Fayyaz, M., Duvvuri, P., Ecta, G. and Bordon, J. (2013) Klebsiella pneumoniae Antimicrobial Drug Resistance, United States, 1998-2010. Emerging Infectious Diseases, 19, 133-136. http://dx.doi.org/10.3201/eid1901.120310

[29] Smith, T.L., Pearson, M.L., Wilcox, K.R., Cruz, C., Lancaster, M.V., Robinson-Dunn, B., Tenover, F.C., Zervos, M.J., Band, J.D., White, E. and Jarvis, M.R. (1999) Emergence of Vancomycin Resistance in Staphylococcus aureus. Glycopeptide-Intermediate Staphylococcus aureus Working Group, The New England Journal of Medicine, 340, 493-501. http://dx.doi.org/10.1056/NEJM199902183400701 


\section{Submit or recommend next manuscript to SCIRP and we will provide best service for you:}

Accepting pre-submission inquiries through Email, Facebook, LinkedIn, Twitter, etc.

A wide selection of journals (inclusive of 9 subjects, more than 200 journals)

Providing 24-hour high-quality service

User-friendly online submission system

Fair and swift peer-review system

Efficient typesetting and proofreading procedure

Display of the result of downloads and visits, as well as the number of cited articles

Maximum dissemination of your research work

Submit your manuscript at: http://papersubmission.scirp.org/ 